\title{
$\mathrm{Cu}-\mathrm{Ni}-\mathrm{P}$ 系合金の析出強化特性に及ぼす ARB 法および冷間圧延法の影響
}

\author{
野 村 幸 矢1 \\ 三輪洋 介 $^{1}$ \\ 高川優作,* \\ 渡邊千尋3 \\ 門 前 亮 ${ }^{3}$ \\ 寺田大将 4 \\ 辻伸 泰 4 \\ 1株式会社神戸製鋼所アルミ・銅事業部門 \\ 2 金沢大学大学院自然科学研究科機能機械科学専攻 \\ 3 金沢大学大学院自然科学研究科システム創成科学専攻 \\ 4京都大学大学院工学研究科材料工学専攻 \\ J. Japan Inst. Metals, Vol. 75, No. 9 (2011), pp. 509-515 \\ (C) 2011 The Japan Institute of Metals

\section{Influence of Accumulative Roll Bonding and Cold Rolling Processes on the Precipitation Strengthening Properties for $\mathrm{Cu}-\mathrm{Ni}-\mathrm{P}$ Alloy}

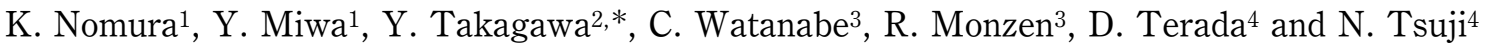 \\ ${ }^{1}$ Aluminum \& Copper Business, Kobe Steel, Ltd., Shimonoseki 752-0953 \\ ${ }^{2}$ Division of Mechanical Science and Engineering, Graduate School of Natural Science \& Technology, Kanazawa University, Kanazawa \\ 920-1192 \\ ${ }^{3}$ Division of Innovative Technology and Science, Graduate School of Natural Science \& Technology, Kanazawa University, Kanazawa \\ 920-1192 \\ ${ }^{4}$ Department of Materials Science and Engineering, Graduate School of Engineering, Kyoto University, Kyoto 606-8501
}

\begin{abstract}
The enhancement of strength of a $\mathrm{Cu}-1.4$ mass $\% \mathrm{Ni}-0.25$ mass $\% \mathrm{P}-0.1$ mass $\% \mathrm{Zr}$ alloy, in which the $\mathrm{Ni}$ and $\mathrm{P}$ contents are about twice larger than those in commercial $\mathrm{Cu}-\mathrm{Ni}-\mathrm{P}$ alloys, has been tried by means of combining accumulative roll-bonding (ARB) process by 7 cycles and aging treatment at 350 to $450^{\circ} \mathrm{C}$. For the sake of comparison, the mechanical properties of the alloy conventionally cold-rolled to a reduction of $50 \%$ and $90 \%$ and aged at 350 to $450^{\circ} \mathrm{C}$ have also been examined. The grain sizes of the $\mathrm{Cu}-\mathrm{Ni}-\mathrm{P}-\mathrm{Zr}$ specimens deformed by 7 -cycle ARB process and $90 \%$ cold-rolling were refined down to about $0.4 \mu \mathrm{m}$ and 4 $\mu \mathrm{m}$, respectively, and the fractions of high angle grain-boundaries in the specimens were nearly the same, about $45 \%$. Initial aging, subsequent $\mathrm{ARB}$ process or $90 \%$ cold-rolling and re-aging at $400^{\circ} \mathrm{C}$ produced the $\mathrm{Cu}-\mathrm{Ni}-\mathrm{P}-\mathrm{Zr}$ alloy highly strengthened. The alloy, initially aged, then ARB-processed and re-aged, had a tensile strength of $780 \mathrm{MPa}$, an elongation of $6 \%$ up to failure and an electrical conductivity of 56\% IACS. The differences in yield strength among the re-aged specimens after $50 \%$ and $90 \%$ cold-rolling and ARB process are explained by the differences among the dislocation density, grain size and inter-precipitate spacing.
\end{abstract}

(Received December 20, 2010; Accepted June 3, 2011)

Keywords: copper-nickel-phosphorus alloy, accumulative roll-bonding process, tensile property, grain refinement strengthening, precipitation strengthening, dislocation strengthening

\section{1. 緒言}

電気電子機器用接続部品には銅合金製端子からなるコネク タが使用されている，これら端子は通電電流容量, 使用環境 に応じてさまざまなデザインやサイズがあり, それらに適し た銅合金が使用されている。これら銅合金に求められる最も 重要な特性は電気接点の良好な接触信頼性を維持する高強度 と通電容量を決定する導電率の二つである，そのため，強度 と導電率のバランスに優れた銅合金が常に求められている. これを満たす合金系の一つに $\mathrm{Cu}-\mathrm{Ni}-\mathrm{P}$ 系合金があり, コネ

*金沢大学大学院生 (Graduate Student, Kanazawa University)
クタやリードフレームとして利用されてきた ${ }^{1,2)}$. 近年, 析 出硬化型 $\mathrm{Cu}-\mathrm{Ni}-\mathrm{P}$ 合金は $\mathrm{Ni}-\mathrm{P}$ めっき付き銅廃材を原料に して鋳造できるという観点から特に注目されており, 高強 度・高導電性，優れた応力緩和特性を有する $\mathrm{Cu}-0.7$ mass \% $\mathrm{Ni}-0.13$ mass $\% \mathrm{P}-0.1$ mass $\% \mathrm{Fe}$ (以後, mass\%を省略) 合金 が開発されている1).この合金では, 引張強さ $670 \mathrm{MPa}$, 伸 び $7 \%$, 導電率 $65 \% \mathrm{IACS}$ にも達する. $0.1 \mathrm{Fe}$ は応力緩和特 性を改善するために添加してある.このような $\mathrm{Cu}-\mathrm{Ni}-\mathrm{P}$ 系 合金では $\mathrm{Ni}$ と $\mathrm{P}$ よりなる金属間化合物が時効により形成さ れ, 強度に寄与している2,3). しかし, Ni と P の含有量が少 なく, 形成される析出物の体積分率が小さいため, 強度への 析出物の寄与は未だ不十分と考えられる。例えば， $\mathrm{Cu}-$ $0.52 \mathrm{Ni}-0.19 \mathrm{P}$ 合金中の $\mathrm{Ni}_{12} \mathrm{P}_{5}$ 析出物の体積分率は 0.006 程 
度2)であり，代表的な高強度・高導電性材料である時効硬化 型 $\mathrm{Cu}-\mathrm{Ni}-\mathrm{Si}$ 系合金(コルソン合金)の中で標準組成を持つ $\mathrm{Cu}-2.0 \mathrm{Ni}-0.5 \mathrm{Si}$ 合金中の $\mathrm{Ni}_{2} \mathrm{Si}$ 析出物のそれは 0.015 程度 ${ }^{4)}$ である。

そこで, 本研究では通常組成より $\mathrm{Ni}$ と $\mathrm{P}$ の量を約 2 倍に 増やし，さらに $\mathrm{Zr}$ を添加した $\mathrm{Cu}-1.4 \mathrm{Ni}-0.25 \mathrm{P}-0.1 \mathrm{Zr}$ 合金 に ARB (Accumulative Roll-Bonding) 加工 ${ }^{5,6)}$ と時効処理を 施し，強度のさらなる向上を試みた。すなわち， Ni と $\mathrm{P} の$ 増量による多少の導電率の低下は犠牲にしても, 析出量の増 加と結晶粒の微細化による強度の向上を図ったものである. 比較のため, $\mathrm{Cu}-\mathrm{Ni}-\mathrm{P}-\mathrm{Zr}$ 合金に 50\%, 90\%圧延と時効処理 を実施し，その機械的性質も調べた.

渡邊ら ${ }^{7,8)}$ は以前に, $\mathrm{Cu}-\mathrm{Ni}-\mathrm{Si}$ 系合金への ECAP(EqualChannel Angular Pressing)法の適用を試みてきたが，作製 された合金は強加工されているため熱的に不安定であり，時 効時にピーク硬さに達する前に再結晶が生じ, 十分な強度を 得ることができなかった。一方， $\mathrm{Cu}$ 基合金に $\mathrm{Zr}$ を微量添 加すると, 再結晶が抑制されることが知られており7), これ が今回の ARB 用試料に $\mathrm{Zr}$ を添加した理由である. $\mathrm{Zr}$ 添加 に加え, ARB 加工前に溶体化処理に続く予備時効を実施す ることにより，続く $\mathrm{ARB}$ 加工後の時効においても再結晶を 抑制してピーク時効を行うことができ, 結果として引張強さ $780 \mathrm{MPa}$ ，伸び $6 \%$ ，導電率 56\%IACS を達成することがで きた．本論文ではこの結果を中心に報告する.

\section{2. 実 験 方 法}

Fig. 1 に試料の作製プロセスフローと試料名表記法を示す. $\mathrm{Cu}-1.4(1.51$ at \% ) Ni-0.25 (0.51 at\%) P-0.1 (0.07 at\%) Zr 合 金を溶製した。ついで $1000^{\circ} \mathrm{C}$ で均質化処理し， $80 \%$ の冷間 圧延を行い， $850^{\circ} \mathrm{C}$ で $1 \mathrm{~h}$ の溶体化処理後水焼き入れを行っ た.この溶体化処理時に再結晶が生じ，結晶粒径は約 50 $\mu \mathrm{m}$ となった。溶体化処理後の試料に $0,50,90 \%$ の冷間圧延 または室温で ARB 加工を行った．これらの試料をそれぞれ CR0，CR50，CR90 および ARB と表記した。これらの試料 に対し，その後塩浴炉を用いて $350 \sim 450^{\circ} \mathrm{C}$ にて時効処理を 施した。 また，溶体化処理に続いて $450^{\circ} \mathrm{C} て ゙ 5 \min の$ 予備 時効を行った後， $50,90 \%$ の冷間圧延または ARB 加工を行 った。これらの試料をそれぞれ $\mathrm{P}-\mathrm{CR} 50, \mathrm{P}-\mathrm{CR} 90$ および $\mathrm{P}-$

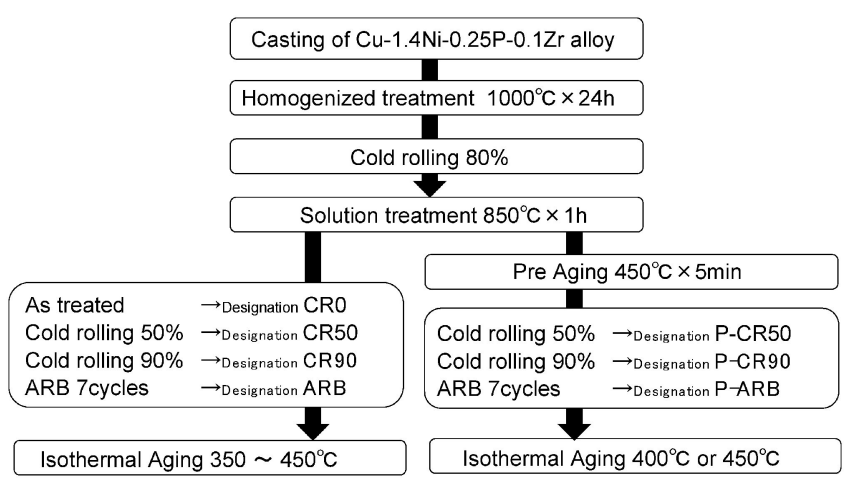

Fig. 1 Schematic process flow and designation of specimens.
$\mathrm{ARB}$ と表記した。これらの試料にさらに $400^{\circ} \mathrm{C}$ まは $450^{\circ} \mathrm{C}$ で時効処理を行うという加工熱処理も実施した。いず れの試料も圧延後または ARB 加工後に時効焼鈍を施した場 合は，各試料名の先頭に aged を表記して区別した.

$450^{\circ} \mathrm{C}$ で時効した CR0, CR50 試料の硬さはそれぞれ $4 \mathrm{~h}$ および $1 \mathrm{~h}$ でピークに達した。しかし，CR90または ARB は，さらにこれより低い $400,350^{\circ} \mathrm{C}$ で時効を実施したとき も, 硬さがピークになる前に光学顕微鏡で再結晶が観察され た.すなわち, $450^{\circ} \mathrm{C}$ で $5 \mathrm{~min}, 400^{\circ} \mathrm{C}$ で $15 \mathrm{~min}, 350^{\circ} \mathrm{C}$ で $1 \mathrm{~h}$ の時効後に再結晶粒が確認され，これに伴って硬さが低 下した，そこで，CR90 抢よび ARBについては再結晶が認 められない $350^{\circ} \mathrm{C}$ で $30 \mathrm{~min}$ の時効を行うこととした. また 溶体化処理後の予備時効条件 $\left(450^{\circ} \mathrm{C} \cdot 5 \mathrm{~min}\right)$ もここから決定 した。

溶体化処理後あるいは $450^{\circ} \mathrm{C}$ で $5 \min$ の時効後の $\mathrm{ARB}$ 加 工に供する試料 (ARB, P-ARB)の寸法は, 冷間圧延の途中 板厚 $1 \mathrm{~mm}$ で切出し, 幅 $30 \mathrm{~mm}$, 長さ $200 \mathrm{~mm}$ とした. 供 試材の接合面は, 圧延前にアセトンによる脱脂とステンレス 線製のワイヤブラシによる研磨を行った，接合面を 2 枚重 ねにした試料を $50 \%$ 冷間接合圧延した後，水冷した。導入 される相当ひずみ量は 1 サイクルで抢よそ0.89)である. 本 研究では ARB 加工を 7 サイクルまで行ったため, 全工程で 与えられる相当ひずみは 5.6 である。な打圧延材 CR50, CR90の相当ひずみはそれぞれ 0.8, 2.7 である.

熱処理後の試料を用いて, 硬さ試験, 導電率測定, 引張試 験を行った．硬さはマイクロビッカース硬度計により $2.9 \mathrm{~N}$, $10 \mathrm{~s}$ の条件にて測定した. 引張試験は, 平行部が $20^{1} \mathrm{~mm} \times$ $6^{\mathrm{w}} \mathrm{mm} \times 0.25^{\mathrm{t}} \mathrm{mm}$ の板状肩付き試験片を用い, 万能引張試 験機により初期ひずみ速度 $3 \times 10^{-4} \mathrm{~s}^{-1}$ の条件で室温大気中 にて行った. 引張方向は圧延方向に平行である. ARB加工 では板厚の $1 / 2$ 付近に最終接合面が存在するが，断面 SEM 観察でも剥離などの欠陥は見られず，接合状態が良好であっ たため機械的特性には影響はないものと判断した。 また，渦 電流式導電率計により室温大気中にて導電率を測定した。

転位密度を評価するため X 線回折実験を行った。(111), (200)，(220),（311)反射のピークの幅(半価幅)から, 補正 された Williamson-Hall 法を用いてひずみを求め, 転位密度 に換算した ${ }^{10)}$.

組織観察は日立製 H-9000NARならびに日本電子製 JEOL2000EX 透過型電子顕微鏡 $(\mathrm{TEM})$ を用いて，それぞれ 加速電圧 $300 \mathrm{kV}, 200 \mathrm{kV}$ にて行った. TEM 観察用薄膜試 料は, ツインジェット法にて $\mathrm{H}_{3} \mathrm{PO}_{4}: \mathrm{CH}_{3} \mathrm{OH}: \mathrm{H}_{2} \mathrm{O}=2$ : $1: 7$ (容積比)ならびに $\mathrm{HNO}_{3}: \mathrm{CH}_{3} \mathrm{OH}=1: 4$ の溶液を用い

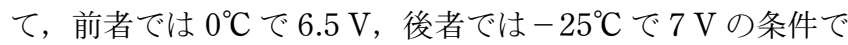
作製した。また，TEM に内蔵されているエネルギー分散型 $\mathrm{X}$ 線分析装置 $(\mathrm{EDS})$ を用いて, $\mathrm{Cu}$ 母相と析出物に電子線を 入射して添加元素の濃度を測定した．用いたビーム直径は 2 $\mathrm{nm}$ であり，調査した膜厚は約 $30 \mathrm{~nm}$ である。さらに， SEM-EBSD (Electron Back-Scattering diffraction)法による 組織観察, 結晶方位解析を行った。 


\section{3. 実 験 結 果}

\section{$3.1 \quad$ ARB 加工材と $90 \%$ 圧延材の組織}

$\mathrm{ARB}$ と $\mathrm{CR} 90$, さらにこれらに $350^{\circ} \mathrm{C}$ にて $30 \mathrm{~min}$ 時効処 理を施した試料について SEM-EBSD 法による組織観察, 結晶方位解析を行った. P-ARB と P-CR90, さらにこれら に $400^{\circ} \mathrm{C}$ で $30 \mathrm{~min}$ 時効処理を施した試料についても同様な 観察，解析を実施した.

Fig. 2(a)はARBの, Fig. 2(b)は CR90の EBSD 測定か ら得られた隣接粒間の結晶方位差分布である.これらの像は 圧延板の縦断面のほぼ中心部から得られた．ここで黒色およ び緑の線は，それぞれ方位差 $15^{\circ}$ 以上の大角粒界と $15^{\circ}$ 未満 の小角粒界を示す。ただし $2^{\circ}$ 以下の亜粒界は取り除いてあ る. ARBでは全体に結晶粒の微細化が進行しており, 圧延 方向に伸張したラメラ状超微細組織が観察される. ARBで はラメラ境界の多くは大きな方位差を持つ大角粒界となって おり，ARB 加工により形成された伸長ラメラ組織は互いに 異なる方位を持つ微細結晶粒からなる多結晶体であることが わかる. CR90 では元の結晶粒が圧延方向に伸長した通常の 加工組織が観察されるが，局所的に結晶粒の微細化が見られ る. Table 1 に, CR90 と ARB, ならびにそれらの時効材 aged CR90 と aged ARB について, 縦断面で圧延方向に垂 直な方向 $(\mathrm{ND})$ に沿った方位差 $2^{\circ}$ 以上の粒界の平均間隔 (結 晶粒径), アスペクト比, 大角粒界の割合を示す. 時効前後 の CR90の結晶粒径は約 $4 \mu \mathrm{m}, \mathrm{ARB}$ のそれは $0.4 \mu \mathrm{m}$ であ り, ARB 加工により結晶粒が微細化されている. ARB 加工 された析出型銅合金のアスペクト比と大角粒界の割合につい ては， 6 サイクル ARB 加工された $\mathrm{Cu}-\mathrm{Cr}-\mathrm{Zr}$ 合金での時効 前後で約 0.25 , 約 $60 \%$ 11) となることが報告されている.こ
れと比較して $\mathrm{Cu}-\mathrm{Ni}-\mathrm{P}$ 系合金は結晶粒が伸長しにくい傾向 があった．時効による母相組織の大きな変化はない。

ARB 加工材およびその時効材の TEM 観察の結果, 両材 の組織の様相は似通って抢り, 高密度の転位を含む, Fig. 2 (a)に似た圧延方向に伸長したラメラ組織を形成していた. 時効後の転位密度が特に減少している様子は見られなかった.

以上の ARB 加工材とその時効材の組織的特徵は, 予備時 効後に ARB 加工した材料とその時効材にもすべて認められ た。

\section{2 引張特性に及ぼす結晶粒微細化と熱処理の効果}

再結晶が認められない時効条件, たとえば CR50を $450^{\circ} \mathrm{C}$ で 1 時間焼鈍した場合には, Fig. 3 の TEM 観察に例示する ように, 球状に近い析出物が形成された. TEM 観察の際の 電子ビーム入射方向は $\mathrm{Cu}$ 母相の $[011] \mathrm{m}$ 方向と平行であ る. この球状粒子は電子回折図形(SADP)の解析により $\mathrm{Ni}_{12} \mathrm{P}_{5}$ 金属間化合物 2 であることがわかった. Fig. 3 に見ら れるように，圧延材と ARB 加工材では転位上に優先析出し ている様子がしばしば観察された。 $\mathrm{Ni}_{12} \mathrm{P}_{5}$ 析出物の他には 析出物は認められなかった。このため $\mathrm{Zr}$ 原子は $\mathrm{Cu}$ 母相に

Table 1 Microstructural parameters obtained from EBSD measurements of the $\mathrm{Cu}-\mathrm{Ni}-\mathrm{P}-\mathrm{Zr}$ specimens, $\mathrm{CR} 90$ and $\mathrm{ARB}$ un-aged and aged at $350^{\circ} \mathrm{C}$ for $30 \mathrm{~min}$.

\begin{tabular}{lccc}
\hline Specimens & $\begin{array}{c}\text { Mean spacing of } \\
\text { boundaries along } \\
\text { ND }(\mu \mathrm{m})\end{array}$ & $\begin{array}{c}\text { Grain aspect } \\
\text { ratio }\end{array}$ & $\begin{array}{c}\text { Fraction of high-angle } \\
\text { boundaries }(\%)\end{array}$ \\
\hline CR90 & 4 & 0.35 & 45 \\
\hline aged CR90 & 4 & 0.40 & 46 \\
\hline ARB & 0.40 & 0.40 & 45 \\
\hline aged ARB & 0.4 & 0.45 & 47 \\
\hline
\end{tabular}

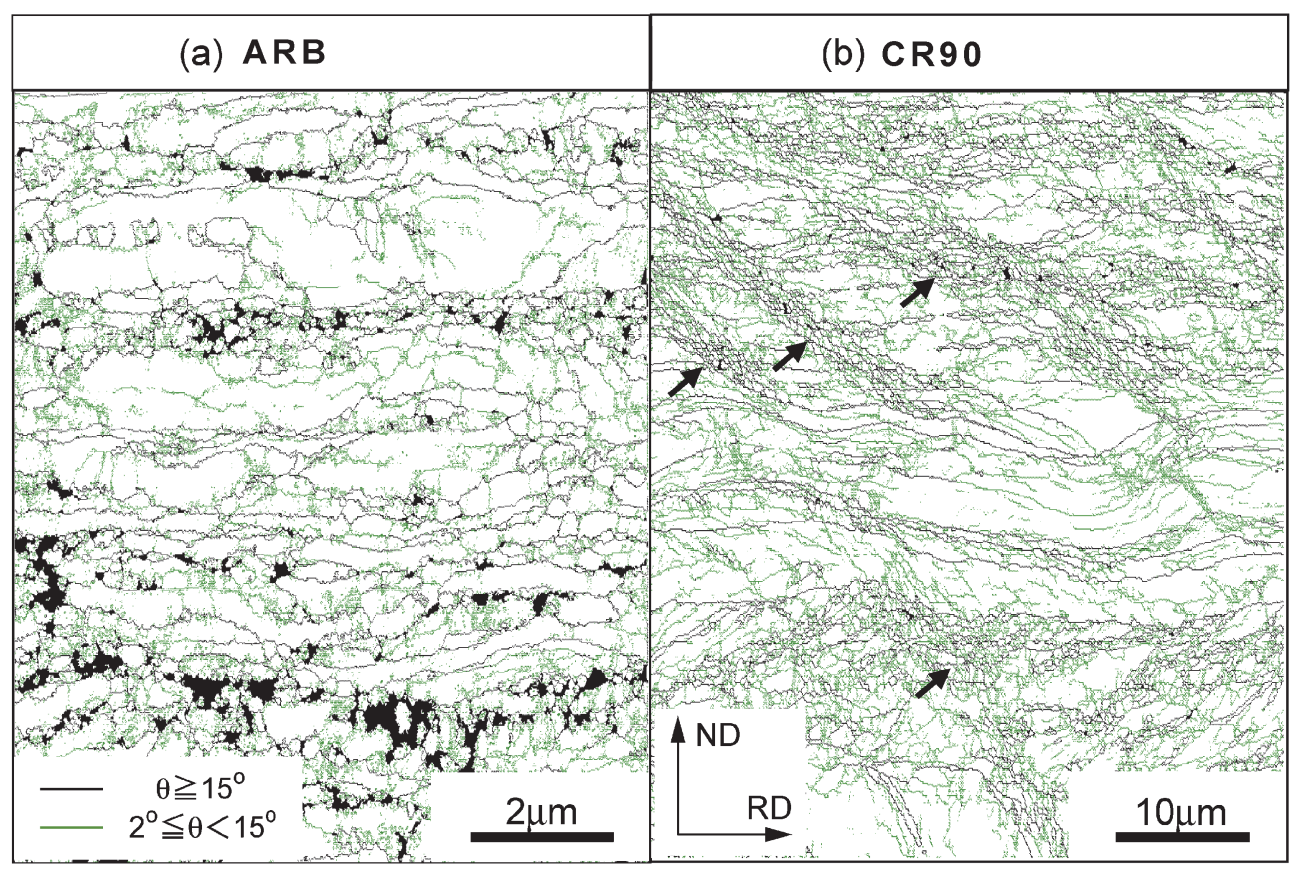

Fig. 2 Distribution of disoriented grains of the $\mathrm{Cu}-1.4 \% \mathrm{Ni}-0.25 \% \mathrm{P}-0.1 \% \mathrm{Zr}$ specimens, (a) ARB specimen and (b) CR90 specimen. In the boundary maps, green lines represent the low-angle boundaries having misorientation $\theta$ of $2^{\circ} \leqq \theta<15^{\circ}$, while black lines indicate the high-angle boundaries with $\theta \geqq 15^{\circ}$. The arrows in (b) indicate the fine grains. 

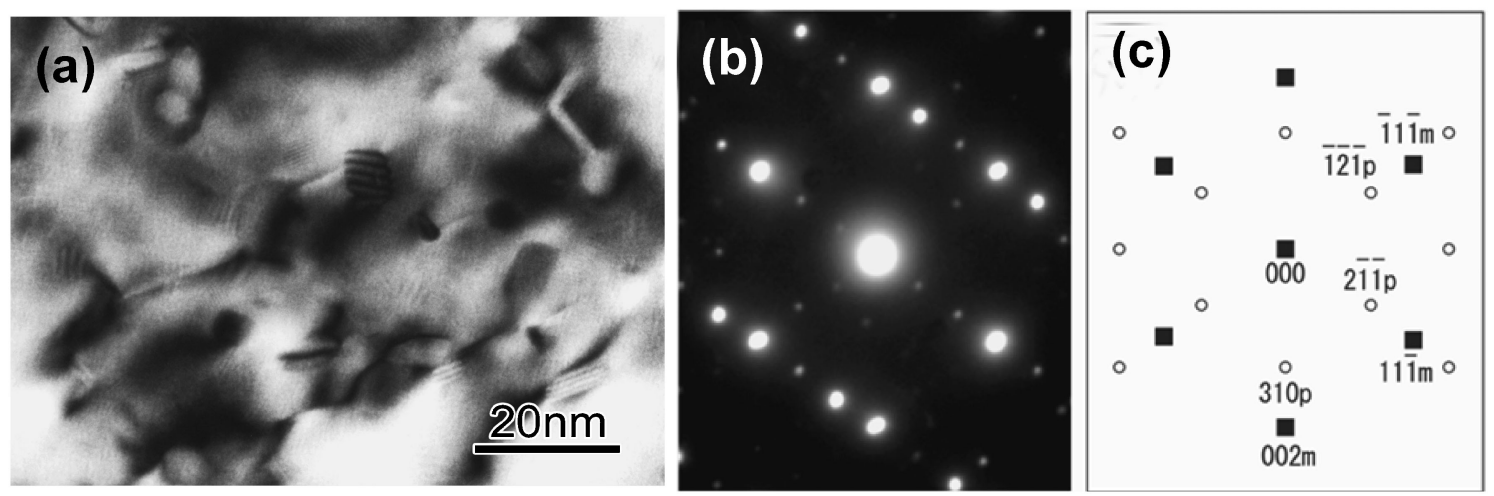

Fig. 3 (a) TEM image of $\mathrm{Ni}_{12} \mathrm{P}_{5}$ precipitates on dislocations in the CR50 specimen aged at $450^{\circ} \mathrm{C}$ for $1 \mathrm{~h}$. (b) $[011] \mathrm{m}$ selected-area diffraction pattern (SADP) corresponding to (a). (c) Schematic illustration of the previous SADP: $\mathbf{\square}=\mathrm{Cu}$ spots, $\bigcirc=\mathrm{Ni}_{12} \mathrm{P}_{5}$ spots.
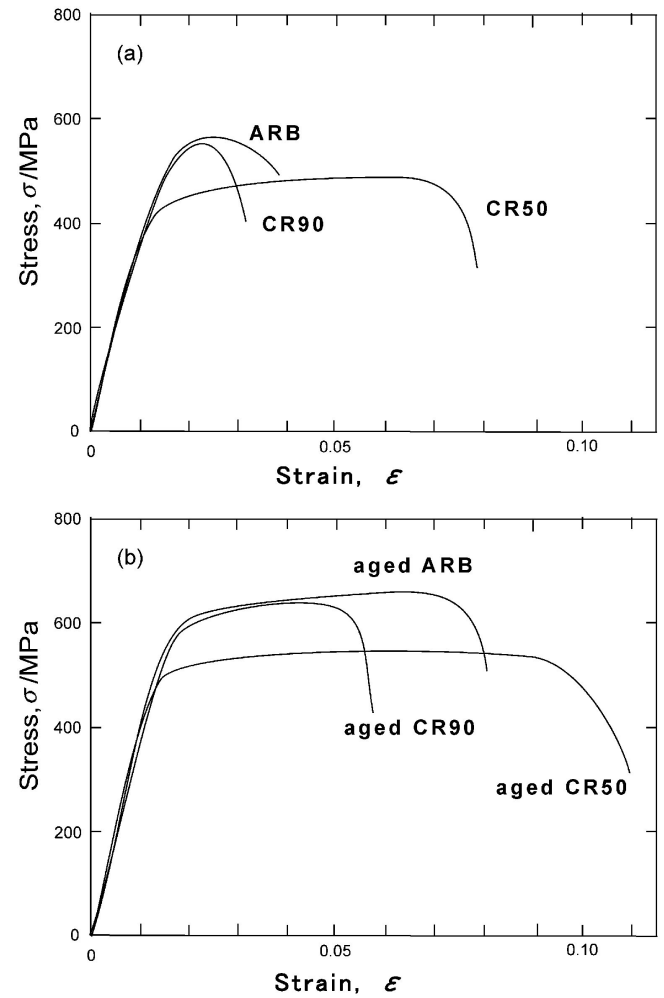

Fig. 4 Stress-strain curves of the $\mathrm{Cu}-\mathrm{Ni}-\mathrm{P}-\mathrm{Zr}$ specimens, (a) CR50, CR90 and ARB, (b) CR50 aged at $400^{\circ} \mathrm{C}$ for $1 \mathrm{~h}$ and $\mathrm{CR} 90$ and $\mathrm{ARB}$ at $350^{\circ} \mathrm{C}$ for $30 \mathrm{~min}$.

固溶していることが予想される，そこで溶体化処理後 $450^{\circ} \mathrm{C}$ で $4 \mathrm{~h}$ 時効した試料を用いて EDS 分析を行った. Cu 母相中 の $\mathrm{Zr}$ の濃度は約 0.1 mass\%であり，これは元素添加量と一 致して打り，また $\mathrm{Ni}_{12} \mathrm{P}_{5}$ 析出物中からは $\mathrm{Zr}$ は検出されなか った。これらのことより $\mathrm{Zr}$ のほとんどは $\mathrm{Cu}$ 母相中に固溶 していると判断される.

Fig. 4(a)は CR50 と CR90 およびARB, Fig. 4(b)はそれ らの時効後の公称応力ーひずみ曲線である. 時効前の CR90 は CR50 より強度は高いが伸びは極端に小さい，ARB は CR90 と同程度の強度を持ち若干大きな伸びを示す。両材と も最初加工硬化しその後くびれが生じ，均一伸びと局部伸び の割合は同程度である. ARB 加工後のこのような特徵は, 純 $\mathrm{Cu}^{12)}$ や $\mathrm{Cu}-0.85 \mathrm{Cr}-0.07 \mathrm{Zr}$ 合金 ${ }^{11)}$ の ARB 材の応力ーひず
Table 2 Grain size $d, 0.2 \%$ proof stress $\sigma_{0.2}$, tensile strength $\sigma_{\mathrm{u}}$, elongation $\varepsilon_{\mathrm{t}}$ and electrical conductivity $E_{\mathrm{c}}$ for the $\mathrm{Cu}-\mathrm{Ni}-\mathrm{P}-$ $\mathrm{Zr}$ specimens, $\mathrm{CR} 0$ aged at $450^{\circ} \mathrm{C}$ for $4 \mathrm{~h}$, and CR50 un-aged and aged at $450^{\circ} \mathrm{C}$ for $1 \mathrm{~h}$ and $\mathrm{CR} 90$ and $\mathrm{ARB}$ at $350^{\circ} \mathrm{C}$ for $30 \mathrm{~min}$.

\begin{tabular}{lccccc}
\hline Specimen & $\begin{array}{c}d \\
\mu \mathrm{m})\end{array}$ & $\begin{array}{c}\sigma_{0.2} \\
(\mathrm{MPa})\end{array}$ & $\begin{array}{c}\sigma_{\mathrm{u}} \\
(\mathrm{MPa})\end{array}$ & $\begin{array}{c}\varepsilon_{\mathrm{t}} \\
(\%)\end{array}$ & $\begin{array}{c}E_{\mathrm{c}} \\
(\% \mathrm{IACS})\end{array}$ \\
\hline aged CR0 & 50 & 370 & 460 & 20 & 49 \\
\hline CR50 & 23 & 420 & 470 & 8 & 25 \\
\hline aged CR50 & 23 & 480 & 540 & 11 & 45 \\
\hline CR90 & 4 & 520 & 550 & 3 & 25 \\
\hline aged CR90 & 4 & 590 & 630 & 6 & 42 \\
\hline ARB & 0.4 & 530 & 560 & 4 & 25 \\
\hline aged ARB & 0.4 & 600 & 640 & 8 & 42 \\
\hline
\end{tabular}

み曲線の特徵とは異なっており, 全伸びは $10 \%$ 程度で局部 伸びがほとんどを占める．時効によりすべての試料の強度と 伸びが増加するが，いずれの試料も時効前と同様に aged ARB は aged CR90 と同程度の強度を持ち, aged CR90よ りも大きな伸びを示す.

Table 2 に, CR50 と CR90 および ABR とその時効後に 抢ける結晶粒径 $d, 0.2 \%$ 耐力 $\sigma_{0.2}$, 引張強さ $\sigma_{\mathrm{u}}$, 伸び $\varepsilon_{\mathrm{t}}$, 導電率 $E_{\mathrm{c}}$ を示す. 圧延を行わずにピーク時効を行った aged CR0 の測定結果も示す. CR50の結晶粒径は SEM 観察から 決定した。なお，溶体化処理後の $\mathrm{Cu}-\mathrm{Ni}-\mathrm{P}$ 合金に $50 \%$ 圧延 を加え $450^{\circ} \mathrm{C} て ゙ 1 \mathrm{~h}$ のピーク時効を行ったときの耐力と引張 強さ2)は, Table 2 の $\mathrm{Cu}-\mathrm{Ni}-\mathrm{P}-\mathrm{Zr}$ 合金に打けるそれらとほ ぼ同じであり，強度への Zr 添加の効果は実質的に認められ なかった。しかし， $\mathrm{Zr}$ は $\mathrm{Cu}$ 母相に固溶するため, 導電率 の低下となって現れた。

Table 2 に扔いて，CR90 は CR50 より強度が高く伸びが 小さい。しかし, ARB は CR90 と比較して結晶粒径が約 1/ 10 であるにもかかわらず，強度と伸びはほとんど差異がな く若干大きい程度にすぎない。導電率は CR $50, \mathrm{CR} 90$ と $\mathrm{ARB}$ で等しい，時効により CR50, CR90 と ARB のいずれ も強度, 導電率抢よび伸びが向上する. しかし, 時効後の $\mathrm{CR} 90$ と $\mathrm{ARB}$ の $0.2 \%$ 耐力と引張強さはほぼ等しく, 結晶 粒微細化の効果が現れていない. 引張強さもこれまでに報告 されている時効後の $\mathrm{Cu}-0.7 \mathrm{Ni}-0.13 \mathrm{P}-0.1 \mathrm{Fe}$ 合金における值, 


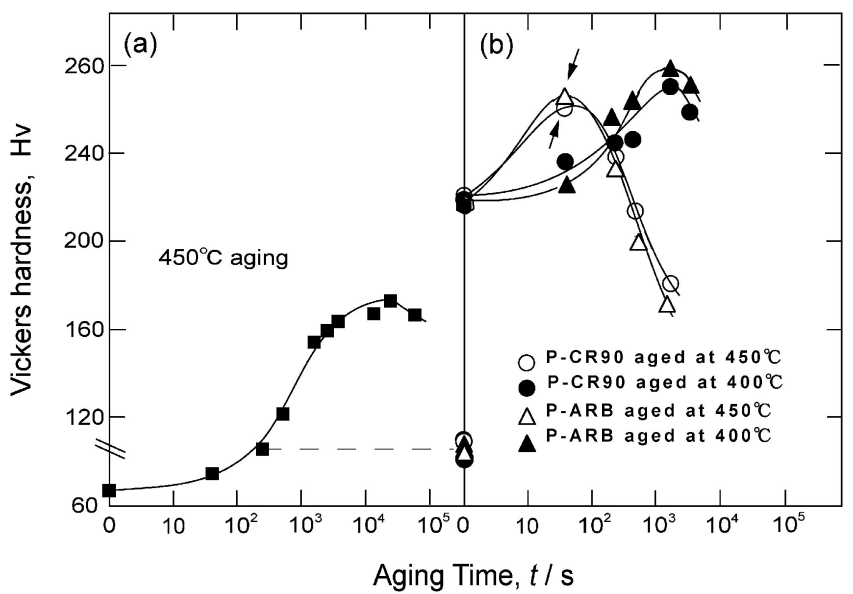

Fig. 5 Age-hardening curves of the $\mathrm{Cu}-\mathrm{Ni}-\mathrm{P}-\mathrm{Zr}$ specimens, (a) CR0 aged at $450^{\circ} \mathrm{C}$, and (b) P-CR90 and P-ARB aged at 400 and $450^{\circ} \mathrm{C}$. The arrows in (b) indicate the start time of recrystallization.

$670 \mathrm{MPa}^{1)}$ より低い值である。一方，時効後の導電率は時効 前の圧下率の増加に伴い低下し, aged CR90 と aged ARB は同じ值となっている。これらの導電率が低いのは, 本研究 ではピーク時効に達する前に再結晶が生じ, 亜時効段階の時 効処理しか行えなかった結果, $\mathrm{Ni}_{12} \mathrm{P}_{5}$ 化合物の析出が十分 でないためと考えられる.

$\mathrm{ARB}$ 加工のような強ひず $久$ 加工法により作製された金属 材料は，一般的に強度は極めて高いが，熱的安定性が乏しい という久点がある. 熱的安定性の改善には, 母相中に微細な 第 2 相粒子を密に分散させて再結晶粒核生成過程に扔ける 転位や亜粒界の移動抢よびその後の再結晶粒成長の拘束力を 高めることが効果的である13)。しかし，CR90 および ARB では, 時効中に形成された析出物の転位や亜粒界の移動に対 するピン止め効果が十分でないため，ピーク時効の前に再結 晶が生じると考えられる。そこでまず $450^{\circ} \mathrm{C}$ で $5 \min$ の予 備時効を行った後に冷間圧延または ARB 加工を行った $\mathrm{P}-$ CR50，P-CR90 抢よび $\mathrm{P}-\mathrm{ARB}$ を再び $450^{\circ} \mathrm{C}$ で時効した。 なお， $450^{\circ} \mathrm{C}, 5 \mathrm{~min}$ の予備時効で, ピーク時効までの析出 硬化量の約 $1 / 3$ の硬化量に達する (Fig. $5(\mathrm{a})) .450^{\circ} \mathrm{C}$ の時 効に扔いて P-CR90, P-ARB ではピーク時効前に再結晶が 起きたが， $400^{\circ} \mathrm{C}$ の時効では再結晶前に硬さのピークが生じ た(Fig. 5(b)).

Fig. 6 (a) に，400年でそれぞれ順に $1 \mathrm{~h}, 30 \mathrm{~min}, 30 \mathrm{~min}$ のピーク時効処理する前の $\mathrm{P}-\mathrm{CR} 50, \mathrm{P}-\mathrm{CR} 90$ お よび $\mathrm{P}-$ ARB の, Fig, 6 (b) にはピーク時効後の公称応力ーひず み曲 線を示す. Fig. 4(a) と（b)の公称応力ーひずみ曲線と比べ, いずれの試料も強度は向上し伸びは減少しているが，曲線の 一般的特徵は類似している.

Table 3 に, P-CR50 P-CR90 および P-ARB の $400^{\circ} \mathrm{C}$ の ピーク時効前後の結晶粒径 $d, 0.2 \%$ 耐力 $\sigma_{0.2}$, 引張強さ $\sigma_{\mathrm{u}}$, 伸び $\varepsilon_{\mathrm{t}}$ ，導電率 $E_{\mathrm{c}}$ を示す. Table 2 の結果と比較して，い ずれの試料においても最終時効後の強度は大幅に増加し, 導 電率, 伸びも向上している. 強度への予備時効の効果は $\mathrm{P}-$ ARB と P-CR90 ではほぼ同じであり, aged P-ARB では引 張強さ $780 \mathrm{MPa}$ ，伸び $6 \%$ ，導電率 56\%IACS にも達して
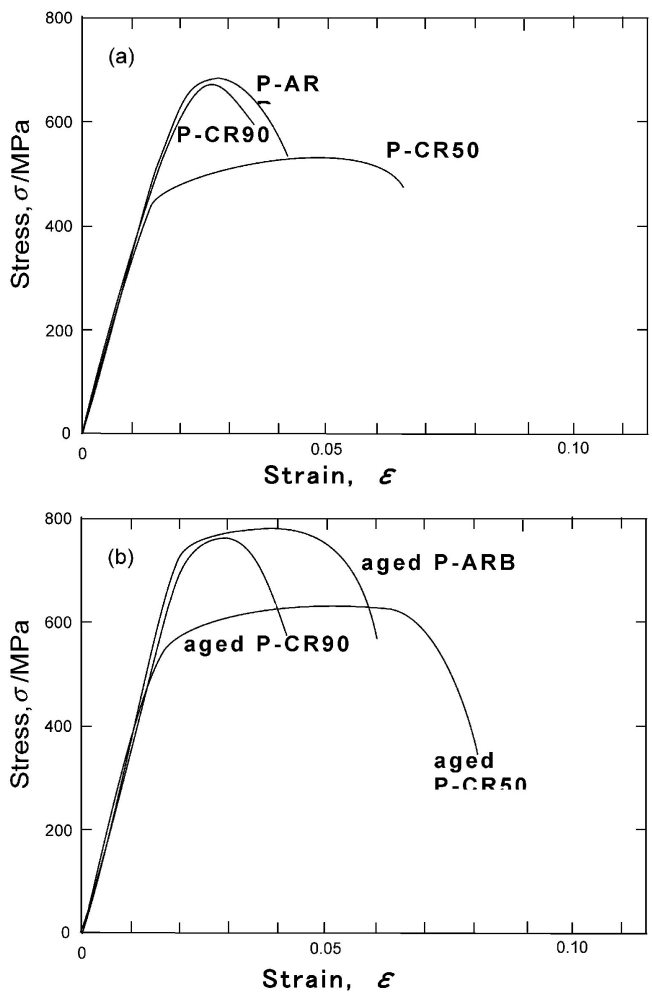

Fig. 6 Stress-strain curves of the $\mathrm{Cu}-\mathrm{Ni}-\mathrm{P}-\mathrm{Zr}$ specimens, (a) $\mathrm{P}-\mathrm{CR} 50, \mathrm{P}-\mathrm{CR} 90$ and $\mathrm{P}-\mathrm{ARB}$, and (b) P-CR50, P-CR90, and $\mathrm{P}-\mathrm{ARB}$ aged at $400^{\circ} \mathrm{C}$ for $1 \mathrm{~h}$ corresponding hardness peak condition.

Table 3 Grain size $d, 0.2 \%$ proof stress $\sigma_{0.2}$, tensile strength $\sigma_{\mathrm{u}}$, elongation $\varepsilon_{\mathrm{t}}$ and electrical conductivity $E_{\mathrm{c}}$ for the $\mathrm{Cu}-\mathrm{Ni}-\mathrm{P}-$ $\mathrm{Zr}$ specimens, $\mathrm{P}-\mathrm{CR} 50$ un-aged and aged at $400^{\circ} \mathrm{C}$ for $1 \mathrm{~h}$, and $\mathrm{P}-\mathrm{CR} 90$ and $\mathrm{P}-\mathrm{ARB}$ un-aged and aged at $400^{\circ} \mathrm{C}$ for $30 \mathrm{~min}$.

\begin{tabular}{lccccc}
\hline \multicolumn{1}{c}{ Specimen } & $\begin{array}{c}d \\
(\mu \mathrm{m})\end{array}$ & $\begin{array}{c}\sigma_{0.2} \\
(\mathrm{MPa})\end{array}$ & $\begin{array}{c}\sigma_{\mathrm{u}} \\
(\mathrm{MPa})\end{array}$ & $\begin{array}{c}\varepsilon_{\mathrm{t}} \\
(\%)\end{array}$ & $\begin{array}{c}E_{\mathrm{c}} \\
(\% \mathrm{IACS})\end{array}$ \\
\hline P-CR50 & 23 & 490 & 540 & 6 & 40 \\
\hline aged P-CR50 & 23 & 570 & 610 & 8 & 50 \\
\hline P-CR90 & 4 & 640 & 670 & 3 & 40 \\
\hline aged P-CR90 & 4 & 730 & 770 & 4 & 56 \\
\hline P-ARB & 0.4 & 650 & 680 & 4 & 40 \\
\hline aged P-ARB & 0.4 & 740 & 780 & 6 & 56 \\
\hline
\end{tabular}

いる.これまでに報告されている時効後の $\mathrm{Cu}-0.7 \mathrm{Ni}-0.13 \mathrm{P}-$ $0.1 \mathrm{Fe}$ 合金に打けるそれらの值，670 MPa, 7\%,65\% $\mathrm{IACS}^{1)}$ と比べ, 導電率は低いが伸びは同程度であり, 引張強さは $110 \mathrm{MPa}$ も大きい.

\section{4. 考察}

時効後の本合金は主として析出強化, 加工強化, 結晶粒微 細化強化によって強化されている. 以下, 本合金に打ける降 伏応力へのこれら 3 つの因子の寄与について検討を加える.

本研究で観察された $\mathrm{Ni}_{12} \mathrm{P}_{5}$ 析出物が存在するとき, ピー ク時効後の本合金の降伏応力はオロワン機構によって支配さ れる ${ }^{2)}$. オロワン応力 $\Delta \sigma_{\text {or }}$ と平均粒子間隔 $\lambda$ には次の関係 がある。 


$$
\Delta \sigma_{\text {or }} \propto \frac{1}{\lambda}
$$

ここで, 析出粒子の平均粒子半径を $r$, 体積分率を $f$ とする と入は

$$
\lambda=r\left\{\left(\frac{2 \pi}{3 f}\right)^{1 / 2}-1.63\right\}
$$

と表せる．析出物の間隔が小さいほど，微細に分布するほど 強度は向上する。 また, 一般に転位密度 $\rho$ と降伏応力 $\Delta \sigma_{\mathrm{d}}$ との間には Bailey-Hirsch の関係 ${ }^{14)}$ が成立することが知られ ている.

$$
\Delta \sigma_{\mathrm{d}}=A \alpha \mu b \sqrt{\rho}
$$

ここで $A$ と $\alpha$ は定数, $\mu$ は剛性率, $b$ はバーガースベクトル の大きさを表す，転位密度が大きいほど強化量は大きくな る.さらに, 降伏応力 $\Delta \sigma_{\mathrm{g}}$ が結晶粒径 $d$ にだけ依存すると き Hall-Petch の関係 ${ }^{15,16) よ り ~}$

$$
\Delta \sigma_{\mathrm{g}}=k d^{-0.5}
$$

と表される， $k$ は定数である. 結晶粒径が小さいほど強化量 は増加する。

Table 4 にCR0, 50, 90 および ARB の時効前後での $0.2 \%$ 耐力 $\sigma_{0.2}$, 式 (2) から計算された析出物間距離 $\lambda, \mathrm{X}$ 線解析 から測定された転位密度 $\rho$, 結晶粒径 $d$ を示す. CR90 と $\mathrm{ARB}$ の時効条件はピーク時効ではないが，析出物の大きさ は CR50のそれとあまり差異がないこと, $\mathrm{Ni}_{12} \mathrm{P}_{5}$ 析出物と $\mathrm{Cu}$ 母相の間には格子の一対一の対応がないことから，オロ ワン機構によって降伏すると仮定した．また，時効前の転位 密度を Table 4 の括弧内に示す.いずれの試料においても, 時効により転位密度が減少したと判断される.さらに， $f$, $r$, 析出物の数密度 $N=f /\left(4 \pi r^{3} / 3\right)$ も示す. ここで $f$ は以下 のようにして求めた．析出粒子の導電率への影響は無視でき るほど小さいので17), 析出粒子の量は時効による溶質濃度 減少量となって現れ，これは導電率变化から見積もることが できる． 3.2 項で述べたように $\mathrm{Zr}$ は実質的に $\mathrm{Cu}$ 母相中に固 溶しているので, 最初に, $\mathrm{Cu}$ 中の $\mathrm{Zr}$ 固溶量と導電率の関 係 ${ }^{18)}$ から，Zr 固溶による導電率の低下分を取り除いた。そ して, $\mathrm{Cu}$ 母相と $\mathrm{Ni}_{12} \mathrm{P}_{5}$ 析出物の格子定数 ${ }^{19)}, \mathrm{Cu}$ の導電率 への $\mathrm{Ni}, \mathrm{P}$ の寄与 ${ }^{18)}$ から $f$ の值を見積もった. なお, Table 4 に見られるように，時効前の CR50の転位密度より CR90 または ARBのそれは 3 倍程度大きい值であるが, Table 2 中の時効前のこれら試料の導電率は等しいため, 時効時の転 位密度の減少による導電率の増加分は無視することができる. aged CR50 の耐力は無圧延材 aged CR0より高い. 析出 物間距離と結晶粒径は実質的に变わらないので，これは主と して転位密度の増加に基づく . aged CR90の耐力はさらに 高くなっている．この強度の増加は転位密度のさらなる増加 に加え, 析出物間距離の減少々結晶粒径の微細化に起因す る。ところが, aged CR90に比べ aged ARB の結晶粒径が 小さいにもかかわらず，両試料の間にほとんど強度の差はな い. 析出物間距離はそれらの試料間では差があまり認められ ないので, 耐力への析出強化の寄与はほぼ同じとみなすこと ができる。しかし転位密度は aged ARBの方が低い。文献 20)中の $A=2, \alpha=0.57, \mu=46 \mathrm{GPa}, b=0.256 \mathrm{~nm}$ ，そして Table 4 の aged ARB と aged CR90 の転位密度を使い式 (3) から, aged ARBの強度が約 $40 \mathrm{MPa}$ 低くなると見積もるこ とができる. 一方, Gertsman ら ${ }^{21)}$ は純 $\mathrm{Cu}$ の降伏応力の結 晶粒径依存性を報告して抢り，その結果より $4 \mu \mathrm{m}$ から 0.4 $\mu \mathrm{m}$ までの結晶粒微細化による降伏強度の上昇は約 $60 \mathrm{MPa}$ と見積もられる。この結晶粒微細化による強度の増加分は転 位密度が低いことによる強度の減少分と概ね等しい. 従って aged CR90 と aged ARBの降伏強度に大きな差は認められ なかったと理解される.

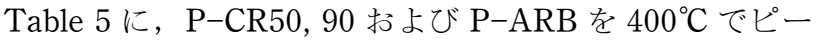
ク時効処理した後の $0.2 \%$ 耐力 $\sigma_{0.2}$, 析出物間距離 $\lambda$, 転位 密度 $\rho$, 結晶粒径 $d$ を示す. $f, r, N$, 時効前の $\rho$ (括弧内) $も$ 示す. ピーク時効前の各試料の転位密度は時効後のそれより 大きく, 時効により転位密度が減少することがわかる. aged P-CR50 より aged P-CR90の強度は高いが, これは転 位密度の増加に加え, 析出物間距離の減少と結晶粒の微細化 による. また, ピーク時効後の aged P-ARB の耐力は aged P-CR90のそれとほぼ同じであり，これは上述のように， aged P-CR90 と比べ結晶粒が微細であることと転位密度が 低いことによる効果が相殺された結果と考えることができる.

Table 4 の結果と比較すると, いずれの試料においても, 時 効前後の転位密度が高い. 時効前に転位密度が高いのは, 転 位の運動が予備時効によって形成される析出物により拘束さ れ，転位が対消滅しにくくなったことによると考えられる. また, Table 5 中の予備時効後の圧延材抒よび ARB 加工材 の耐力は Table 4 中の予備時効なしのそれらに比べ，それぞ れ 90, 140, $140 \mathrm{MPa}$ 大きい。これら耐力の増加は転位密度 の増加と析出物間距離の減少に起因する. 各試料において耐 力の増加分のうち加工強化の寄与分は, 式(3)からそれぞれ

\begin{tabular}{|c|c|c|c|c|c|c|c|}
\hline Specimen & $\begin{array}{c}\sigma_{0.2} \\
(\mathrm{MPa})\end{array}$ & $f$ & $\begin{array}{c}r \\
(\mathrm{~nm})\end{array}$ & $\underset{\left(\times 10^{21} / \mathrm{m}^{-3}\right)}{N}$ & $\begin{array}{c}\lambda \\
(\mathrm{nm})\end{array}$ & $\begin{array}{c}\rho \\
\left(\times 10^{14} / \mathrm{m}^{-2}\right)\end{array}$ & $\begin{array}{c}d \\
(\mu \mathrm{m})\end{array}$ \\
\hline aged CR0 & 370 & 0.0114 & 7.0 & 8.0 & 85 & - & 50 \\
\hline aged CR50 & 480 & 0.0103 & 6.5 & 9.0 & 82 & $\begin{array}{c}1.0 \pm 0.2 \\
(1.3 \pm 0.1)\end{array}$ & 23 \\
\hline aged CR90 & 590 & 0.0094 & 5.2 & 16 & 69 & $\begin{array}{c}3.5 \pm 0.1 \\
(4.0 \pm 0.3)\end{array}$ & 4 \\
\hline aged ARB & 600 & 0.0094 & 5.0 & 18 & 66 & $\begin{array}{c}2.6 \pm 0.2 \\
(3.0 \pm 0.1)\end{array}$ & 0.4 \\
\hline
\end{tabular}

Table $4 \quad 0.2 \%$ proof stress $\sigma_{0.2}$, volume fraction $f$ of $\mathrm{Ni}_{12} \mathrm{P}_{5}$ precipitates, precipitate radius $r$, precipitate number density $N$, interprecipitate spacing $\lambda$, dislocation density $\rho$, and grain size $d$ for the $\mathrm{Cu}-\mathrm{Ni}-\mathrm{P}-\mathrm{Zr}$ specimens, CR0 aged at $450^{\circ} \mathrm{C}$ for $4 \mathrm{~h}$ and $\mathrm{CR} 50$ aged at $450^{\circ} \mathrm{C}$ for $1 \mathrm{~h}$, and $\mathrm{CR} 90$ and $\mathrm{ARB}$ aged at $350^{\circ} \mathrm{C}$ for $30 \mathrm{~min}$. 
Table $50.2 \%$ proof stress $\sigma_{0.2}$, volume fraction $f$ of $\mathrm{Ni}_{12} \mathrm{P}_{5}$ precipitates, precipitate radius $r$, precipitate number density $N$, interprecipitate spacing $\lambda$, dislocation density $\rho$, and grain size $d$ for the $\mathrm{Cu}-\mathrm{Ni}-\mathrm{P}-\mathrm{Zr}$ specimens, peak-aged $\mathrm{P}-\mathrm{CR} 50$ at $400^{\circ} \mathrm{C}$ for $1 \mathrm{~h}$, and peakaged $\mathrm{P}-\mathrm{CR} 90$ and $\mathrm{P}-\mathrm{ARB}$ at $400^{\circ} \mathrm{C}$ for $30 \mathrm{~min}$.

\begin{tabular}{cccccccc}
\hline Specimen & $\begin{array}{c}\sigma_{0.2} \\
(\mathrm{MPa})\end{array}$ & $f$ & $\begin{array}{c}r \\
(\mathrm{~nm})\end{array}$ & $\begin{array}{c}N \\
\left(\times 10^{21} / \mathrm{m}^{-3}\right)\end{array}$ & $\begin{array}{c}\lambda \\
(\mathrm{nm})\end{array}$ & $\begin{array}{c}\rho \\
\left(\times 10^{14} / \mathrm{m}^{-2}\right)\end{array}$ & $\begin{array}{c}d \\
(\mu \mathrm{m})\end{array}$ \\
\hline aged P-CR50 & 570 & 0.0112 & 5.4 & 21 & 64 & $\begin{array}{c}1.9 \pm 0.4 \\
(3.0 \pm 0.2)\end{array}$ & 23 \\
\hline aged P-CR90 & 730 & 0.0124 & 3.8 & 37 & 46 & $\begin{array}{r}6.1 \pm 0.2 \\
(7.0 \pm 0.3)\end{array}$ & 4 \\
\hline aged P-ARB & 740 & 0.0124 & 4.0 & 36 & 45 & $\begin{array}{c}4.8 \pm 0.2 \\
(5.5 \pm 0.1)\end{array}$ & 0.4 \\
\hline
\end{tabular}

60, 80, $80 \mathrm{MPa}$ と見積もることができる.

ピーク時効により形成される析出物の数密度を概算する. 予備時効, すなわち $450^{\circ} \mathrm{C}$ で $5 \mathrm{~min}$ の時効で析出物の核生 成が完了したと仮定する。このとき析出核の数密度は, Table 4 中の無圧延材 (aged CR0)の析出物の数密度と概ね 等しいと考えられる. 従って, 2 回目の時効によって形成さ れる析出物の数密度は, aged P-CR50, aged P-CR90, aged P-ARB においてそれぞれ $1.3 \times 10^{22} ， 2.9 \times 10^{22} ， 2.8 \times 10^{22}$ $\mathrm{m}^{-3}$ と概算することができる。これらの值は Table 4 中の aged CR50, aged CR90, aged ARB の数密度の值より 2 倍程 度大きい. 2 回目の時効により形成される析出物は 1 回だけ の時効によるものより明らかに過飽和度が低い状態で形成さ れたものである。それにもかかわらず，2 回目の時効後に各 試料中の析出物の数密度が高いのは, 核生成位置となる時効 前の転位密度が高いことによると考えられる.

Table 5 で, aged P-ARBのピーク時効前の転位密度 (括 弧内)は aged P-CR90のそれより低い。この原因は明らか ではないが，ARB 加工材中の転位密度を加工率 $90 \%$ の圧延 材レベルまで上げることができれば，時効後の ARB 加工材 の強度はさらに向上するはずである. ARB 加工された純 $\mathrm{Cu}$ や $\mathrm{Al}$ 中の転位密度は相当ひずみに依存することが報告され ており22), 従って ARB 加工材に与える相当ひずみ量を変え ることによって転位密度が増加する可能性がある．このこと も含めて現在検討中である.

\section{5. 結言}

本研究では実用 $\mathrm{Cu}-\mathrm{Ni}-\mathrm{P}$ 系合金の通常組成より $\mathrm{Ni}$ と $\mathrm{P}$ の量を約 2 倍に増やし, さらに $\mathrm{Zr}$ を添加した $\mathrm{Cu}-1.4 \mathrm{Ni}-$ $0.25 \mathrm{P}-0.1 \mathrm{Zr}$ 合金に 7 サイクルの $\mathrm{ARB}$ 加工と $350 \sim 450^{\circ} \mathrm{C}$ の時効処理を併用し強度の向上を試みた。比較のため，50, $90 \%$ 圧延と時効処理を併用した同合金の機械的性質も調べ た. 得られた結果は以下のように要約される.

（1） ARB 加工または 90\%圧延により，大角粒界の割合が ともに約 $45 \%$, 平均結晶粒径が約 $400 \mathrm{~nm}$ または $4 \mu \mathrm{m}$ の微 細粒からなるラメラ組織が形成された。

（2）予備時効後 ARB 加工または $90 \%$ 圧延を行い，さら に $400^{\circ} \mathrm{C}$ のピーク時効を施すことにより，強度の高い材料 を作製することができた．特に ARB 加工を適用したとき， 引張強さ $780 \mathrm{MPa}$, 伸び $6 \%$, 導電率 $56 \% \mathrm{IACS}$ の特性が
得られた。

(3) $50 \%$ と $90 \%$ 圧延材ならびに ARB 材のピーク時効後 の降伏強度の違いは, 転位密度, 結晶粒径, 析出物間距離の 違いから説明することができる.

本研究の一部は, 文部科学省先端研究施設供用イノベーシ ヨン創出事業【ナノテクノロジー・ネットワーク】の支援を 受けて，京都・先端ナノテク総合支援ネットワークに抢いて 実施されたことを付記し，謝意を表する，また，著者の一部 (寺田, 辻) は, 文部科学省科学研究費補助金新学術領域研究 「バルクナノメタルー常識を覆す新しい構造材料の科学」の援 助を受けた.

\section{文献}

1) R. Ozaki and Y. Miwa: R\&D Kobe Steel Engineering Reports 57 No. 1 (2007) 110.

2) K. Nomura, Y. Miwa, Y. Shimada, C. Watanabe and R. Monzen: J. Japan Inst. Metals 74(2010) 325-330.

3) J. Miyake and M. E. Fine: Acta Metall. Mater. 40(1992) 733741.

4) K. Shimodaira, N. Tanabe, C. Watanabe and R. Monzen: J. JRICu 48(2009) 135-139.

5) Y. Saito, N. Tsuji, H. Utsunomiya, T. Sakai and R. G. Hong: Scr. Mater. 39(1998) 1221-1227.

6) N. Tsuji, Y. Ito, Y. Saito and Y. Minamino: Scr. Mater. 47 (2002) 893-899.

7) C. Watanabe, H. Hiraide, Z. Zhang and R. Monzen: J. Soc. Mater. Sci., Japan 54(2005) 717-723.

8) C. Watanabe, M. Miyakoshi, F. Nishijima and R. Monzen: J. JRICu 45(2006) 16-22.

9) T. Sakai, Y. Saito, T. Kanzaki, N. Tamashiro and N. Tsuji: J. JRICu 40(2001) 213-217.

10) T. Kunieda, M. Nakai, Y. Murata, T. Koyama and M. Morinaga: ISIJ Int. 45(2005) 1909-1914.

11) N. Takata, Y. Ohtake, K. Kita, K. Kitagawa and N. Tsuji: Scr. Mater. 60(2009) 590-593.

12) N. Takata, S.-H. Lee, C.-Y. Lim, S.-S. Kim and N. Tsuji: J Nanosci. Nanotechnol. 7 (2007) 3985-3989.

13) K. Kita, K. Kobayashi and R. Monzen: J. Soc. Mater. Sci., Japan 49(2000) 482-487.

14) J. E. Bailey and P. B. Hirsch: Philos. Mag. 5(1960) 485-497.

15) E. O. Hall: Proc. Phys. Soc. B 64(1951) 747-753.

16) N. J. Petch: J. Iron Steel Inst. 174(1953) 25-28.

17) A. Boltax: Trans. AIME 218 (1960) 812-821.

18) S. Komatsu: J. JRICu 41(2002) 1-9.

19) H. W. Hoppel, J. May, P. Eisenlohr and M. Goken: Z. Metallk. 96 (2005) 566-571.

20) M. R. Staker and D. L. Holt: Acta Metall. 20(1972) 569-579.

21) V. Y. Gertsman, M. Haffmann, H. Gleiter and R. Biringer: Acta Metall. Mater. 42(1994) 3539-3544.

22) Y. Murata, I. Nakata and M. Morinaga: Mater. Trans. 49 (2008) 20-23. 